\title{
SPOTKANIA Z LUDŹMI I KULTURĄ W POEZJI MIRONA BIALOSZEWSKIEGO LEONARDO I TWARZE Z MATEJKI
}

\author{
Colloquia Litteraria \\ UKSW \\ $4 / 52008$
}

\section{JAN FALKOWSKI}

Osobliwa ${ }^{1}$ na pozór konstrukcja - z indeksem, od którego wszystko się zaczyna - wyjaśni się później.

Indeks malarzy u Białoszewskiego:

(cyfra rzymska - numer tomu według Utworów zebranych ${ }^{2}$;

cyfra arabska - numer strony;

OtM - O tym Mickiewiczu jak go mówię;

kursywa - malarz niewymieniony z nazwiska, ale wiadomo, że o niego chodzi) Angelico Fra OtM 294

- Bonnard Pierre I 117; VIII 167

„- a bo do tych prostot to się dochodzi po wielu doświadczeniach. Jak który malarz nie robił aktów męskich, to znaczy, że lubiał baby. A jak ma akt męski, to już znak, że coś. Jak dwa, to oho. David ma tylu nagich chłopców. Okazuje się, że chłopców lubiał. Prosty sprawdzian. Weiss same baby. Bonnard ani jednego aktu męskiego. Renoir? O właśnie, od tego powinienem zacząć, same baby, a zrobił swojego syna Coco, to go ubabszczył. To te najprostsze prawdy." (Traf, $R$, VIII 167)

${ }^{1}$ Poniższy tekst jest fragmentem większej pracy pt. „Pan Mozart, pan Bach, pani Reginka, ja”. Spotkania z ludźmi i kulturq w poezji Mirona Białoszewskiego.

${ }^{2}$ M. Białoszewski, Utwory zebrane, t. 1-7, Warszawa 1987-1994. 


\section{- Bosch Hieronim V 100}

„Miało być uduchowienie, natchnienie. I jest, ciagnie się. Ale cielesność robi psikusy. Duchy też. Chce się ich jak dymu, i to już grzeszek. Potem się ściemnia. W oczach ciemność mruga, błyska. Burza nieraz idzie. Ta omamowa. Duchy się kłębią, a to już wymiary wypukłe i zmienne.

Bosch. No tak. To z tego. I inni. I naprawdę ci, co siedzieli po kątach świata. Tacy, siacy, pustelnicy. Nie pomoże jeść mało i sucho. To czasem sprzyja. Im się właśnie takie różności ulatniały z kamienia zamyślenia. Dymiły, krążyły nad głową. Cieliły się i kusiły.” (Frywole - 3, Szzc, V 100)

- Boticelli Sandro VIII 159

- Boznańska Olga VIII 161

„Czytam zdanie: «Urządzenie nie pretendowało do starożytności, chyba że epokę wiktoriańską nazwiemy starożytną.» Zdanie sobie sprawy, że to żywe może być u mnie, dla kogoś to zabytek, bo sprzed trzydziestu lat. Boznańska, która wychodziła na ulicę ubrana po prostu $\mathrm{w}$ to, co miała. A że to nie było już modne..." (Traf, $R$, VIII 161)

\section{- Brueghel Pieter VIII 78; IX 243}

„Dwupłatowiec znów krążył, wzbijał się z koło, aż wypuścił z siebie niby mucha $z$ bzykiem te swoje. Zlatywały, rozwijały się po drodze $z$ nieba na trawę. A to obłoczki.

Spadochrony jako tako widać, ludzie robaczkowi. Nic dziwnego, że Ikar, jak spadał, to go nikt nie zauważył, chlup. Ale skąd Bruegel to wiedział? Oni wiedzieli wszystko. Jak wyglądają obłoki z góry, jak się podfruwa, przysiada na gzymsie." (Ch, VIII 78)

„Centrum nieduże z wieżowcami, niezbyt ludne. Dwie Wieże Babel na kilkanaście pięter. I takie jak u Breugla. Jedna to magistrat. A druga dworzec kolejowy." ( $A$, IX 243)

- Cellini Benvenuto V 252

- Czyżewski Tytus V 73 cyt. zob. Leonardo da Vinci 
- David Jacques-Louis IV 182; VIII 167 cyt. zob. Bonnard Pierre

- Dürer Albrecht IV 81

- Eyck Jan van VIII 164 cyt. zob. Rembrandt Harmenszoon van Rijn

- Fidiasz VII 94 cyt. zob. Karpiński Franciszek

- Goya Francisco IV 259

- Goes Hugo van der VIII 164 cyt. zob. Rembrandt Harmenszoon van Rijn

- Gogh Vincent van VIII 176

„A wtedy, co ja nie wiedziałem, czy siwa kość jeszcze miła w ręku, czy nie, to zdaje się, że ona miała wypisane na papierze «Kostka dla Vincenta». Bo pudel ma na imię jak van Gogh.” (Traf, $R$, VIII 176)

- Greco El I 151-152; VIII 154-155, 157, 164

„drętwiałem bez stylu

jak w dzieciństwie

jeszcze na most

ale na niepokój

według El Greca

zmartwychwstałem

w jego neonach

w tym samym rzucie

i szaleństwie"

(Mosty pierworodne i El Greco wybawiajacy, I 151-152)

„- El Greco walił biel na chama. Teraz się boją bieli. Dawniej nie. On kładł biel, a dopiero na tym inne kolory, dlatego tak świecą i są gładkie. Tego jest grubo, ale to jest wyrównane tym wyślizgiem." (Traf, $R$, VIII 155)

„Plac Dąbrowskiego. Le. przygląda się rozwieszonym dwóm reprodukcjom El Greca.

- El Greco bije wszystko. Oryginalny. I jednocześnie maluje jak chce. Ten 
anioł ze Zwiastowania ma pióra z indyka. Ona typowa Hiszpanka. Jak ten anioł się utrzymuje?

- Na obłoku, troszkę nad podłogą. Ona cisnęła robótka, nożyczki, o widzisz...

- To to wiadomo. Ten anioł patrzy nie na nią, a na swoją rękę.

- A Duch Święty głębiej, ale między nimi, smuga po nim na niebie jak po samolocie.

- Po Duchu Świętym zawsze są smugi jak po samolocie. Żeby nie malarstwo, to w ogóle... co by... co by ludzkość była warta." (Traf, $R$, VIII 157)

- Hogarth William VI 167

- Ingres Jean IV 182

- Kandinski Wasilij II 178

- Kossak Wojciech IV 243-245

- Leonardo da Vinci I 38, 415; IV 82-83, 276; V 70-71, 73, 252; VI 27-28, 51; VII 94; VIII 159, 165, 201; X 136, 142-143, 149, 157

,$[\ldots]$

A one w Leonardach min,

W obrotach Rafaela

$[\ldots] "$

(Karuzela z madonnami, Or, I 38)

„Wracamy przed obraz. [...]

Le. zbiera wnioski:

- Nie czarna, a czerwona. Nie zacięta, a łagodna, przełagodna. Nie prymitywna, a majsterska. Mniej bizantyjska, więcej Leonardowska. Piękna jako kobieta. Nos prosty, usta pełne, obciągnięte cieniutką białą linią jak nowiem księżyca... Smutna i uśmiechnięta. Polska Gioconda." (Cała noc u Matki Boskiej, Dr, IV 276)

„Wpadam na deptak Luwru. Ten gościnny. Nie trzeba pytać, bo jakoś wiadomo. Architektura wnętrza żenująco kolorowa. Widzę thumek, pewnie przed Giocondą. Od tłumku odbija postać z rozkrzyżowanymi rękami, w palcie 
- z kołnierzem z wydry - jak określił Lu.

brwi Sobole nastroszone

- tutaj nie można się spóźniać.

Gioconda ma przed sobą kwadracik z palików i pluszowych balasków. Balaski przed Giocondą niby są od kradzieży, od kamieni, bo ktoś niedawno cisnął. Ale to nie ten sam, co porąbał Piete Michała Anioła." (Ja i Artur S. w Paryżu, Szzc, V 71)

„Na Giocondę wtedy nie popatrzałem. Trochę ze wzgardy, że taka oklepana. A trochę z uprzedzenia Tytusa Czyżewskiego, który do Lu. powiedział złośliwie o Giocondzie

- to piernik.

Aż raz stanąłem. Spojrzałem. Żaden piernik. Byłem tak oczarowany, zawstydzony.

Nie, nie... Są rzeczy, których nic się nie czepi..." (Ja i Artur S. w Paryżu, Szzc, V 73)

„Le. mnie za to opowiada, że wiadomo było, że Leonardo da Vinci napisał dwa kodeksy. Jeden jest w Londynie. O drugim były słuchy, że dostał go od samego Leonarda przyjaciel Leonardowskiej służącej, sam malarz, że ten malarz odziedziczył zresztą po Leonardzie wszystko, że cenił sobie nadzwyczaj rzeczy mistrza, ale jak mu było trzeba pieniędzy, to coś czasem sprzedał. I tak sprzedał Leonardowski kodeks do Hiszpanii podobno. Tylko że nikt nie wiedział, gdzie ten kodeks jest. Dopiero teraz jeden szukał śpiewek ludowych, a przypadkowo trafił na kodeks Leonarda da Vinci. Dano maszynom cybernetycznym do sprawdzenia teksty i rysunki. Padło pytanie

- skąd te rysunki?

Maszyny odpowiedziały

- Leonardo robił te rysunki z własnego ciała.

Sposób odpowiedzi przekonał uczonych do uwierzenia. Zresztą na końcu kodeksu jest zastanawiające zdanie: «Czytaj mnie, bo rzadko przychodzę na świat.»

Le. mówił jeszcze, że Leonardo zachwycał się własnym ciałem. I to mu się spodobało." (Szpital, Z, VI 27-28)

„Pan Nowy miał dwa razy odwiedziny rodzinne. Dwie średniostarszawe kobiety, dwoje dzieci i młodzieniec trochę z Leonarda da Vinci, z puklami włosów, z anielskim bystrym wejrzeniem z przymieszką uśmiechu i filuterności." (Szpital, Z, VI 51) 
„- Trudniej jest malować z pamięci niż z modela. Pan Kochanek z Krosna mówił mi o Leonardowskim sposobie, Ja zastanawiałem się, co to takiego. A to chodzi o typ modela. To model. Z pamięci - tyle, że musi być obserwacja. To coś więcej niż portret. Stworzenie typu. To co Leonardo.”(Traf, $R$, VIII 159)

„Jeśli o mnie chodzi, to już wolę, żebyśmy byli kosmicznie sami, niż gdyby się miało okazać, że jacyś tam dyktowali nam różności, budowali za nas piramidy, podstawiali Hammurabiego i Leonarda da Vinci i zdalnie sterowali, dopuszczając mnie do zaszczytu, moim natchnieniem. Lepiej stracić największą sensację niż zyskać taki despekt.

A gdyby Bóg? Z Bogiem sprawa jednak wygląda ciekawiej i wieloznaczniej, z perspektywami w obie strony." (Traf, $R$, VIII 165)

„doły

puste

smoki wyzdychały

fiszbiny po nich wiszą

leonardowskie"

(Wasza wczasowiczowska maść, Wiw, VIII 201)

„Korytarz

pusto

śćmione światło,

idę,

w loży u sióstr

uśmiecha się

znajoma?

tak... to ona

Gioconda"

([Korytarz...], Oho, X 136)

„usiadłem pod wiszącym drzewem,

tu może być popołudnie Giocondy, dalej koty, śmietnik, kokony z gipsu

po kończynach (coś dla Leonarda), w porządku:

Giocondzie też to i tamto zalatywało"

([usiadtem pod wiszacym drzewem...], Oho, X 149) 
- Matejko Jan IV 190; V 6, 161, 274; VI 25; VIII 9, 16

„Reszta - to portrety, czterdziestu królów Matejki. Litografowane. Ten słynny poczet. [...]

Trwało to dość długo. Kolejność królów na tapetach dobra. Bo pamiętałem nawet, że Olbracht przed Aleksandrem." (Ostatnia Marszałkowa, Dr, IV 189-190)

„Przesiadka w podziemiu. Włażę w ten młyn. Zawsze mi służy.

O, Bolesław Śmiały...

Przystanął pod ścianą. Oczy niebieskie, włosy piastowskie, nos zadarty, i to nastroszenie, i to wejrzenie, i zaskok, i Matejko. Humor. Już mam. Wpadam w tramwaj. Zapisuję. Wysiadka, wysepka, zapisuję. Na Foksal też. Który to autor robi przed wydawnictwem? A ja jeszcze piszę na schodach.” (Po krzyku, po tomiku, Szzc, V 6)

„Długowłosy je najwięcej, bo jest dość potężny, uprawiał boks. Ma nie tylko pulchne loki, ale i wąsy. Lecą dwoma strumykami do końca głowy. Od połowy drogi to już włosy udające wąsy. Dziś przebudziłem się rano, spojrzałem na niego

- Bolesław Chrobry z Matejki, no tak...” (Szpital, Z, VI 25)

„Obok mieszkała Zosia Romanowska, moja przyszywana ciotka. Za niąpani Bachman, krawcowa, którą nazywali «Zygmunt Stary» na mój wniosek w epoce przyglądania się Pocztowi królów polskich Matejki." (Leszno 99, Sż, VIII 9)

„Nad otomaną wisiała Bitwa pod Grunwaldem. Duża reprodukcja za szkłem w ramach. To szkło kiedyś się stłukło i kawałek utkwił w dole, nad ramą, zawsze mi się kojarzył z chorągwią krzyżacką i z Witoldem na koniu. I nie wiem, czy to Witold, czy kto inny siedzi przodem do końskiego ogona. Na suficie był zaciek, duży, skomplikowany. Nawet ciekawszy od Bitwy pod Grunwaldem, chociaż jeszcze mniej zrozumiały." (Nanka, Sż, VIII 16)

- Matisse Henri I 117

- Mehoffer Józef V 282

„Labirynt pod ziemią to labirynt. Wieczne źródło. Wieczne źródło radości. Takie źródło w kwadrat. Zalewane ludźmi. Za Alejami siedzą gdzie się da, przy PKO, pod knajpa, na tarasikach, na ławkach, na wazonach, ci w cieniu, 
ci w słońcu. Jedna z zielonymi powiekami, przechylona do opalania w tył, jak w tataraku, jak sadzawka, Mehoffer, tyle nastroju i hecy takie jedne powieki oddane ciepłu." (Raj, Szzc, V 282)

- Michelangelo Buonarroti V 71 cyt. zob. Leonardo da Vinci, V 252

- Murillo Bartolomé Estéban V 51; IX 137

,- na tych różnych obrazach nie ma przesady. Na przykład Kuchnia anielska Murilla. Aniołowie za zakonników myją rondle, wszystko jakieś pół metra nad posadzka, wedle ludzkiej miary." (Nadzwyczajnosteczki, Szzc, V 51)

- Rafael Santi I 38 cyt. zob. Leonardo da Vinci; VIII 43

- Rembrandt Harmenszoon van Rijn IV 9; VIII 159, 164

„Syn Marnotrawny (Rembrandta) ma w pięcie wszystkie problemy malarstwa.

Lu." (Cytaty, Dr, IV 9)

„- Nieraz z daleka to ładnie, a z bliska podejść...

- Tak, podszedłem do jednego obrazu, a tu z bliska takie niebieskie, ale jakie linie. Kolor wpakowany, a z daleka...

Le.:

- To u Rembrandta tak. Z bliska takie wyraźne odgraniczenia kolorów, aż wyrżnięte.

- Tak tak, wiem, pamiętam, jak mnie to dziwiło, jak warstwice.

- Chcieli podchodzić z nosami na obraz, a on odganiał." (Traf, $R$, VIII 159)

„,- No, to mało który malarz umiał tak i jedno i drugie. Rembrandt potem wszystko dawał na światłocień. Impresjoniści na światło

- A kto robił i światło, i kolor? El Greco?

- Van Goes, u Van Eycka to jest, u niektórych Holendrów." (Traf, R, VIII 164)

- Renoir Auguste VII 206; VIII 167 cyt. zob. Bonnard Pierre 


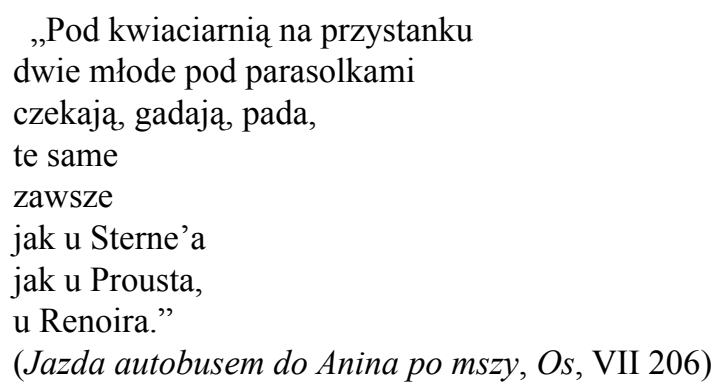

- Ribera José de VIII 159

„Ja:

- Ribera dawniej aż mnie odpychał cielskowatością. To krzyżowanie Andrzeja, ciało amarantowe

- straszny naturalista

- zmarszczki takie z gniewu u młodych chłopców-oprawców. Na nogi świętego spojrzałem: Co to takiego? Włoski? Jedne koło drugich? Założyłem okulary, sprawdzam, a to siateczka pękań.” (Traf, $R$, VIII 159)

- Stabrowski Kazimierz VIII 166

- Stwosz Wit IV 269

„Na innej komodzie wykaz mszy. Kiedy i za kogo.

- Za Macocha kilka razy. To za tego Macocha?

- No pewnie - Le. na to. - To nie było tak dawno. Ale w Krakowie była raz msza za Wita Stwosza. W Kościele katolickim wszyscy umarli są nieoddaleni." (Cała noc u Matki Boskiej, Dr, IV 269)

- Szczepkowski Jan IV 271

- Trzcińska-Kamińska Zofia VIII 148, 163

- Utrillo Maurice V 71-72

Terborch Gerard IV 24

Toulouse-Lautrec Henri de I 168 
Turner William VIII 154

Tycjan VIII 159; IX 137

,Ja:

- Doża wenecki Tycjana z worem pieniędzy mnie zdziwił. Nie ma tam tych laserunków, jak w tym Złożeniu do grobu w Luwrze

- Bo w Luwrze później malowane. To na starość te laserunki. Tamtych poprzednich zaczął nie uznawać. Wziął się do przerabiania. Ludziom to się nie podobało. Mówili: «Stary zwariował.»” (Traf, $R$, VIII 159-160)

- Velázquez Diego I 412

- Weiss Wojciech VIII 167 cyt. zob. Bonnard Pierre

- Witkacy właśc. Witkiewicz Stanisław Ignacy IV 12

- Wyspiański Stanisław II 185; III 17; IV 243; V 5; VIII 55, 108 109; OtM 296, 297

\section{Zabawa w rachunki?}

Teksty Białoszewskiego całe utkane są ze spotkań z ludźmi. Czy warto te spotkania uporządkować i sklasyfikować? A jeśli tak, to w jaki sposób? Wszystkich opisać się przecież nie da. Komentator poezji Białoszewskiego staje przed nie lada problemem, bo jednak chciałby zbadać chociaż tyle, aby z czystym sumieniem móc stwierdzić, że oto poszerzył wiedzę o interesującym go autorze choć o milimetr.

Próba skonstruowania indeksu postaci występujących w twórczości Białoszewskiego to przedsięwzięcie metodologicznie osobliwe i karkołomne: ze względu na obfitość materiału i na kłopoty z wyborem kryteriów jego porządkowania. Zresztą, po co to właściwie robić? Czy przybędzie nam wiedzy na temat znaczeń jakiejkolwiek twórczości, jeśli poznamy frekwencję przywoływania w niej postaci jakiegoś typu? Czy skrupulatne liczenie poszczególnych osób nie jest jedynie wyrazem badawczej bezsilności? Próbą zaprowadzenia własnych porządków w przestrzeni już zbadanej i nazwanej? 
Choć zdawałem sobie sprawę $\mathrm{z}$ różnych niebezpieczeństw czyhających na potencjalnego twórcę podobnego indeksu, podjąłem się kilkukrotnego przewertowania wszystkich dziesięciu tomów Utworów zebranych Białoszewskiego (uwzględniłem również tekst $O$ tym Mickiewiczu jak go mówię niepublikowany w ramach Utworów zebranych - w poszukiwaniu postaci związanych z (szeroko rozumianą) kulturą. Uczyniłem to, wiedząc, że dotychczas nikt tego nie zrobił, przypuszczając, że nikt nigdy tego nie zrobi, i w przekonaniu, że właśnie indeksy (od których sam często rozpoczynam lekturę książek) mogą nie tylko ułatwić czytelnikom swobodnie poruszanie się po rozległych i rozgałęzionych przestrzeniach twórczości interesującego nas pisarza, ale również być ważnym narzędziem interpretacji tej twórczości. Próba ta jest równocześnie jednym z możliwych sposobów na ogarnięcie w całości przynajmniej jakiegoś konkretnego aspektu twórczości Białoszewskiego. Nietypowy układ mojej pracy, z indeksem otwierającym całość, nie tylko podkreśla jego znaczenie jako narzędzia badawczego, ale pokazuje również przebieg działań badawczych, jakie podjąłem.

Wybrałem pięć kategorii, w obrębie których indeks nosi znamiona kompletności. (Nie jest jednak, rzecz jasna, słownikiem ani konkordancją; zawiera co najwyżej elementy konkordancji - w postaci obszernego wyboru cytatów). Owych pięć kategorii to kolejno: malarze, kompozytorzy, pisarze polscy, pisarze obcy oraz - w indeksie o innym charakterze - Bóg, święci i postacie znane z Biblii. Wydaje się, że twórcy zaliczani do czterech pierwszych z wymienionych kategorii stanowią dla Białoszewskiego absolutny kanon kulturowy.

Postanowiłem zbadać, kto w istocie spośród twórców kultury jest dla Białoszewskiego najważniejszy, kto ważny, kto go inspiruje jako poetę, kogo ceni wyżej, a kogo niżej i dlaczego? Wreszcie, bez kogo z tych twórców Białoszewski nie może żyć na co dzień, a bez kogo może się obejść. Już samo odnotowanie liczby literackich epizodów, w których występują poszczególni bohaterowie, może doprowadzić do zaskakujących wniosków, stawiających poetę w zupełnie nowym świetle.

Bo oto okazuje się, że wielbiciel kulturowych peryferii ponad wszystko stawia Bacha. Piewca śmieci wyżej ceni jednak Leonarda 
da Vinci, a nie kupę szmat. Poeta osobny, przekreślający literacką tradycję, pełnymi garściami czerpie z Szekspira i Mickiewicza.

\section{Leonardo i twarze $z$ Matejki}

Wszystko wskazuje na to, że edukacja malarska Białoszewskiego zaczęła się od poznania wiszącej nad otomaną Bitwy pod Grunwaldem Matejki. I choć ówczesna, krytyczna refleksja małego Mirona na temat, obrazu miała, rzecz jasna, raczej charakter prostych, dziecinnych wyobrażeń („szkło kiedyś się stłukło i kawałek utkwił w dole, nad ramą, zawsze mi się kojarzył z choragwią krzyżacką i z Witoldem na koniu. I nie wiem, czy to Witold, czy kto inny siedzi”3), a pod względem wrażeń artystycznych wyżej cenił w tym czasie mały obserwator sztuki „duży, skomplikowany"4 zaciek na suficie, zainteresowanie Białoszewskiego malarstwem (podobnie zreszta jak i zaciekami) przetrwało. I to przetrwało w niezmienionej właściwie formie dziecięcego olśnienia i zadziwienia dziełem.

Tak jak w dzieciństwie częściowa dewastacja reprodukcji zza szyby była powodem zdziwienia, ale i impulsem do rzeczowej analizy (dlaczego jeden $\mathrm{z}$ bohaterów obrazu siedzi na koniu niezgodnie $\mathrm{z}$ powszechnie przyjętą normą - ,przodem do [...] ogona"5), tak i później, w „dorosłym” już obcowaniu Białoszewskiego z malarstwem, drobny szczegół (np. domniemane włoski na nogach świętego z obrazu Ribery albo anioł El Greca opatrzony piórami z indyka) mógł stać się przedmiotem zainteresowania, powodem stawiania pytań oraz budzić szerszą refleksję na temat sztuki.

Białoszewski zna się na sztuce (zwłaszcza malarstwie), ale chyba nie jest ekspertem w tej dziedzinie. Raczej uważnym (niekiedy błyskotliwym) jej obserwatorem i miłośnikiem. Sam chętnie pyta (,A kto robił i światło, i kolor? El Greco?”'), przede wszystkim Le. (swego głównego przewodnika po świecie malarstwa) o rozwiązania

\footnotetext{
${ }^{3}$ Nanka, Sż, VIII 16.

${ }^{4}$ Tamże.

${ }^{5}$ Tamże.

${ }^{6}$ Traf, $R$, VIII 164.
} 
techniczne poszczególnych artystów („El Greco walił biel na chama”, „To u Rembrandta tak. Z bliska takie wyraźne odgraniczenia kolorów, aż wyrżnięte", „[Tycjan - J. F.] na starość te laserunki”") i dzieli się swoimi konkretnymi spostrzeżeniami: „Ribera dawniej aż mnie odpychał swoją cielskowatością" ${ }^{10}$, „Doża wenecki z worem pieniędzy mnie zadziwił”"11, „Aż raz stanąłem. Spojrzałem [na Giocondę - J. F.]. Żaden piernik" ${ }^{\prime 2}$.

Le., który sam przecież jest malarzem, zna więc warsztat od kuchni, wciela się czasem w postać uniwersyteckiego wykładowcy, który „zbiera wnioski”: ,- Nie czarna, a czerwona. Nie zacięta, a łagodna, przełagodna. Nie prymitywna, a majsterska. Mniej bizantyjska, więcej Leonardowska. Piękna jako kobieta. Nos prosty, usta pełne, obciagnięte cieniutką białą linią jak nowiem księżyca..."13 Le., którego zainteresowania malarskie obejmują i bardziej prozaiczną tematykę, objaśnia również, że

jak który malarz nie robił aktów męskich, to znaczy, że lubiał baby. A jak ma akt męski, to już znak, że coś. Jak dwa, to oho. David ma tylu nagich chłopców. Okazuje się, że chłopców lubiał. Prosty sprawdzian. Weiss same baby. Bonnard ani jednego aktu męskiego. Renoir? O właśnie, od tego powinienem zacząć, same baby, a zrobił swojego syna Coco, to go ubabszczył. To te najprostsze prawdy ${ }^{14}$.

W obu wypadkach Le. wymienia cały szereg obserwacji, będących jakby podsumowaniem wykładów: o obrazie Matki Boskiej i o „nagościach" u różnych malarzy. Białoszewski, niczym pokorny uczeń, słucha i, niczym dociekliwy student, dopytuje.

\footnotetext{
7 Tamże, 155.

${ }^{8}$ Tamże, 159.

9 Tamże, 160.

10 Tamże, 159.

11 Tamże.

${ }^{12}$ Ja i Artur S. w Paryżu, Szzc, V 73.

${ }^{13}$ Cała noc u Matki Boskiej, Dr, IV 276.

${ }^{14}$ Traf, $R$, VIII 167.
} 
Zadziwia jednak w tych rozmowach o sztuce osobliwy język opisu malarskich wrażeń. Ani Białoszewski jako słuchacz, ani Le. jako „objaśniacz" sztuki nie stronią od dosadnego formułowania dostrzeżonych malarskich prawd. Cytowaliśmy już uwagę Le. o mało subtelnym sposobie nakładania bieli przez El Greca oraz o tym, że sławny obraz Leonarda to jednak w mniemaniu Białoszewskiego żaden ,piernik”. Czy uwagi w rodzaju: „walił biel na chama”, „lubiał baby”, „kolor wpakowany” "15, „cielskowatość” mógłby wypowiedzieć historyk sztuki podczas wykładu albo w rozprawie naukowej? Raczej nie. A czy inni literaci piszący o swoich kontaktach ze sztuką posłużyliby się podobnymi sformułowaniami?

Zbigniew Herbert, choć tak jak Białoszewski z upodobaniem przypatruje się najmniej nawet na pozór istotnym szczegółom artystycznej działalności człowieka, jak choćby twórczości pewnego holenderskiego malarza, o którym „opowiadano anegdoty, jak to całymi dniami maluje miotły i szczotki, włosek po włosku"16 (Miron badał w podobnym aspekcie jeden z obrazów Ribery: „Na nogi świętego spojrzałem: Co to takiego? Włoski? Jedne koło drugich? Założyłem okulary, sprawdzam, a to siateczka pękań" ${ }^{17}$ ), posługuje się bardziej stonowanym, eleganckim językiem: „Dou był malarzem poszukiwanym i wiecznie młodym. Ciepły, nieco słodkawy koloryt, mistrzowska gra światła, nieskazitelny, precyzyjny rysunek”"18 albo: „Najbardziej fascynujące było tło. Czarne, głębokie jak przepaść, a zarazem płaskie jak lustro, dotykalne i gubiące się $\mathrm{w}$ perspektywach nieskończoności. Przeźroczysta pokrywa czeluści"19.

Opisy Białoszewskiego nie są tak „literackie”, mają raczej charakter zwięzłych, fachowych sprawozdań z kolejnych artystycznych doświadczeń, dostrzeżenia nowych, intrygujących szczegółów lub pomysłów interpretacyjnych dotyczących konkretnych twórców lub dzieł. Nie pi-

\footnotetext{
${ }^{15}$ Tamże, 159.

${ }^{16}$ Zbigniew Herbert, Martwa natura z wędzidlem, Warszawa 2003, s. 29.

${ }^{17}$ Traf, $R$, VIII 159.

${ }^{18}$ Zbigniew Herbert, dz. cyt., s. 29.

${ }^{19}$ Tamże, s. 76.
} 
sze przecież eseju o sztuce, jego malarskie uwagi i skojarzenia rozsiane są po całej twórczości i stanowią tylko jeden z kilku nieodłącznych składników całego pisarstwa.

Chociaż obaj poeci w tak rożny sposób opisują swoje artystyczne doświadczenia, w podobny sposób obcują ze sztuką. Według Herberta

krótki wypad z autokaru nie daje pojęcia o tym, czym jest świątynia grecka. Trzeba spędzić wśród kolumn przynajmniej jeden dzień, aby zrozumieć życie kamieni w słońcu. Zmieniają się one zależnie od pory dnia i roku. Rankiem wapień Paestum jest szary, w południe miodowy, o zachodzie słońca płomienisty. Dotykam go i czuję ciepło ludzkiego ciała. Jak dreszcz przebiegają po nim jaszczurki ${ }^{20}$.

Białoszewski, który nie zawsze dysponuje równie komfortowymi warunkami zwiedzania, podczas swego jednodniowego pobytu w Grecji, gdy „wycieczka pojechała na statek na obiad”, wchodzi „,po południu drugi raz na Akropol. Teraz już prywatnie"21. Jego również nie zadowala krótki slalom pomiędzy starożytnymi budynkami. Chce wdrapać się ponownie na Areopag i jeszcze raz z bliska wszystko obejrzeć. Posuwa się wolno „po śliskich, bardzo śliskich stopniach”22. I podobnie jak Herbert, który nie tylko uważnie śledził zmiany w kolorystyce otoczenia zależne od pory dnia, ale również odczuwał obecność i „ciepło ludzkiego ciała” wśród majestatycznych, pozornie zimnych ścian, odczuwa niewidzialną łączność z tymi, którzy wspinali się po tych stopniach przed wiekami:

Czy to ci ojcowie miasta tak wyślizgali, ci filozofowie, Platoni, Sokratesy? A jeżeli nie oni, to jak oni tu wchodzili? Jak siadali na tych zimnych kamieniach? Mieli chyba wprawę?23

Szacowne zabytki przestają być deptanym co dzień przez setki turystów fragmentem krajobrazu. Starożytne mury ożywają.

\footnotetext{
${ }^{20}$ Zbigniew Herbert, Barbarzyńca w ogrodzie, Warszawa 2004, s. 35.

${ }^{21} O E$, IX 206.

${ }^{22} O E$, IX 207.

${ }^{23}$ Tamże.
} 
Obu poetom zależy na niespiesznym i, na ile to tylko możliwe, pełnym spotkaniu z odwiedzanymi miejscami, z oglądanymi obrazami. Pragną nie tylko zachwycać się kunsztem i precyzją autora podziwianych dzieł, lecz również dowiedzieć się, kto przed wiekami przesiadywał na stopniach Areopagu, kto przechadzał się między kolumnami świątyń Paestum.

Obaj najchętniej zwiedzają na własną rękę: Herberta irytuje ,przewodnik beznamiętnym głosem podający wymiary świątyń z dokładnością buchaltera" ${ }^{24}$, Białoszewski notuje: „Jedna ze starych pań [...] chciała też $[\ldots]$ zwiedzać dodatkowo, nawet chciała się do mnie przyłączyć i ja jakoś się z tym pogodziłem"25. Obaj wolą wędrówki nieopisane w przewodnikach, samodzielne. Obaj próbują potem napotkane dzieła opisać. Jak jednak „opisać zachwyt na widok dzieła sztuki w sposób spokojny, ścisły, rzeczowy, a zarazem utrwalający wzruszenie?" 26 Herbertowi zdaniem Herlinga to się udaje: „Żadnych «ochów» i «achów», żadnych banałów w stylu turystyki sentymentalnej, żadnych kolorowych widokówek, żadnych obowiązkowych marszrut i westchnień" ${ }^{27}$. Czy udaje się Białoszewskiemu?

Uważny obserwator sztuki nigdy nie chodzi ze spuszczoną głową. A uważny obserwator i pisarz w jednej osobie może opatrzyć zwięzłym, fachowym komentarzem nawet upstrzone malunkami domorosłych artystów wagony nowojorskiego metra: „Wsiadamy w pociąg obsmarowany rysunkami, malunkami. Mijamy taki sam. Pytam się mojego opiekuna, czy to jeden amatormalarz obmalowywał te pociągi. Okazuje się, że to dzieci. Wolno było obsmarować w środku i z wierzchu. Rzeczywiście, wagony w środku też są obsmarowane. Teraz już nie wolno"28. Ta wyczerpująca relacja tylko na pozór jest obojętna, bo po chwili Miron celnie zauważa, że ,,system obmalowywania jedną techniką dla wszystkich. Stąd jedność

${ }^{24}$ Zbigniew Herbert, dz. cyt., s. 34-35.

${ }^{25} \mathrm{OE}$, IX 206.

${ }^{26}$ Gustaw Herling-Grudziński, „Barbarzyńca w ogrodzie” Zbigniewa Herberta, [w:] tenże, Pisma zebrane, t. 9, Wyjścia z milczenia, Warszawa 1998, s. 332.

${ }^{27}$ Tamże, s. 332 - 333.

${ }^{28} A$, IX 221. 
stylu”29. Twórczość naścienną, a właściwie „nawagonna”, która jest częścią rzeczywistości, a więc przedmiotem godnym opisu, podsumowuje Białoszewski z chłodnym dystansem i znawstwem.

Białoszewski spotyka się więc ze sztuką przynajmniej na trzech płaszczyznach. Nieodzownym warunkiem mówienia i pisania o sztuce jest dla niego bezpośrednie, osobiste oglądanie, dotykanie dzieła (,,podszedłem do jednego obrazu”30, „,założyłem okulary, sprawdzam”"31). Aby zaś podzielić się swoimi wrażeniami i zaproponować interpretację konkretnego dzieła, dyskutuje Białoszewski z Le., najczęściej w formie bezpośrednio przytoczonego dialogu:

Le. przygląda się rozwieszonym dwóm reprodukcjom El Greca.

- El Greco bije wszystko. Oryginalny. I jednocześnie maluje jak chce.

Ten anioł ze Zwiastowania ma pióra z indyka. Ona typowa Hiszpanka. Jak ten anioł się utrzymuje?

- Na obłoku, troszkę nad podłogą. Ona cisnęła robótką, nożyczki, o widzisz...

- To to wiadomo. Ten anioł patrzy nie na nią, a na swoją rękę.

- A Duch Święty głębiej, ale między nimi, smuga po nim na niebie jak po samolocie ${ }^{32}$.

Dialogi te tylko pozornie notowane są „na gorąco”. Często wieńczy je przecież ogólniejsza, wydaje się, że nienotowana w pośpiechu, refleksja o sztuce, jej funkcjach, a nawet znaczeniu dla ludzkości:

- Po Duchu Świętym zawsze są smugi jak po samolocie. Żeby nie malarstwo, to w ogóle... co by... co by ludzkość była warta ${ }^{33}$.

Ponadto spotkania z poszczególnymi dziełami są dla Białoszewskiego często tylko pretekstem do spotkań $\mathrm{z}$ ich autorami albo innymi ich odbiorcami. Czytelnik Białoszewskiego popada jednak w lekkie zdzi-

\footnotetext{
29 Tamże, 222.

${ }^{30}$ Traf, $R$, VIII 159.

31 Tamże.

32 Tamże, 157.

${ }^{33}$ Tamże.
} 
wienie, kiedy odkrywa, że mechanizm ten z podobną częstotliwością działa i w drugą stronę.

Poza intrygującą kilkuletniego Mirona Bitwa pod Grunwaldem, równie ważnym źródłem malarskim jest Poczet królów polskich Matejki. Oglądany pasjami zbiór portretów stał się ważnym kulturowym kontekstem dla Białoszewskiego i tak bardzo przeniknął do świadomości poety, że mijani na ulicy przechodnie wydają mu się postaciami polskich królów:

Przesiadka w podziemiu. Włażę w ten młyn. Zawsze mi służy.

O, Bolesław Śmiały...

Przystanął pod ścianą. Oczy niebieskie, włosy piastowskie, nos zadarty, i to nastroszenie, i to wejrzenie, i zaskok, i Matejko ${ }^{34}$.

A pacjent z sąsiedniego łóżka w szpitalu przypomina Bolesława Chrobrego:

Długowłosy je najwięcej, bo jest dość potężny, uprawiał boks. Ma nie tylko pulchne loki, ale i wąsy. Lecą dwoma strumykami do końca głowy. Od połowy drogi to już włosy udające wąsy. Dziś przebudziłem się rano, spojrzałem na niego

- Bolesław Chrobry z Matejki, no tak... ${ }^{35}$

Zresztą już w dzieciństwie Mirona, „panią Bachman, krawcowa, [...] nazywali «Zygmunt Stary» na mój wniosek w epoce przyglądania się Pocztowi królów polskich Matejki"36.

Matejkowskie skojarzenia (tym razem z Kazaniem Skargi) budzi także ksiądz wygłaszający ,nad tłumem [...] ze stułą, z rozpostartymi rękoma" ${ }^{37}$ kazanie w dzień św. Józefa.

Wyobraźnia Białoszewskiego tak bardzo nasiąknięta jest malarstwem, że nawet nieznajomi widziani w przelocie wyglądem przypo-

\footnotetext{
${ }^{34}$ Po krzyku, po tomiku, Szzc, V 6.

${ }^{35}$ Szpital, Z, VI 25.

${ }^{36}$ Leszno 99, Sż, VIII 9.

${ }^{37}$ Święte obrzydzenie, Szzc, V 161.
} 
minają mu postacie z obrazów. Nie tylko Matejko zresztą ma taką siłę oddziaływania.

Aby właściwie opisać odwiedzających chorego z sąsiedniego szpitalnego łóżka, Miron posługuje się kategoriami „leonardowskimi”:

Pan Nowy miał dwa razy odwiedziny rodzinne. Dwie średniostarszawe kobiety, dwoje dzieci i młodzieniec trochę z Leonarda da Vinci, z puklami włosów, z anielskim bystrym wejrzeniem z przymieszką uśmiechu i filuterności ${ }^{38}$.

Oglądane z okna autobusu kobiety ,pod kwiaciarnią na przystanku / dwie młode pod parasolkami" ${ }^{39}$ budzą skojarzenia z malarstwem impresjonistów (,te same / zawsze / jak [...] / u Renoira"40). Ciepłe i leniwe popołudnie w śródmieściu Warszawy przywodzi na myśl obrazy Mehoffera:

Za Alejami siedzą gdzie się da, przy PKO, pod knajpa, na tarasikach, na ławkach, na wazonach, ci w cieniu, ci w słońcu. Jedna z zielonymi powiekami, przechylona do opalania w tył, jak w tataraku, jak sadzawka, Mehoffer, tyle nastroju i hecy takie jedne powieki oddane ciepłu ${ }^{41}$.

Widzimy więc, że nałogowo odbywane wizyty w muzeach, przeglądanie albumów, szczegółowe analizy, zadziwienia na widok, pytania i dociekania dotyczące oglądanych przez Białoszewskiego obrazów nie są dla niego czynnościami wystarczającymi do pełnego kontaktu ze sztuką. Dopiero spotkania z innymi ludźmi ożywiają w wyobraźni poety wszystkie te dawne portrety, układy kompozycyjne i decyzje malarskie podjęte najczęściej przed wiekami. Czy możemy zatem powiedzieć, że malarstwo pomaga Białoszewskiemu w pełniejszym kontakcie z drugim człowiekiem?

\footnotetext{
${ }^{38}$ Szpital, Z, VI 51.

${ }^{39}$ Jazda autobusem do Anina po mszy, Os, VII 206.

40 Tamże.

${ }^{41}$ Raj, Szzc, V 282.
} 
Gdybyśmy to samo pytanie odnieśli do Gombrowicza, okazałoby się, że nie. Sama wizyta w muzeum sztuki jest dla niego bowiem psychiczną męczarnią:

Wczoraj wybrałem się do Museo National de Bellas Artes z N.N., ulegając jego namowom. Nadmiar obowiązków zmęczył mnie zanim jeszcze przystąpiłem do ich ogląanania; chodziliśmy od sali do sali; przystawaliśmy przed którymś z obrazów; po czym podchodziliśmy do innego obrazu ${ }^{42}$.

Czy możemy sobie wyobrazić Gombrowicza ochoczo wdrapującego się dwa razy w ciagu jednego dnia na Akropol? „Ulegając [...] namowom" towarzysza pisarz realizuje obowiązkową marszrutę od obrazu do obrazu, nie wykazując nadmiernego entuzjazmu: ,ziałem apatią, która mieniła się barwami obrzydzenia, niechęci, buntu, złości, absurdu." ${ }^{43}$ Zresztą bardziej zajęty wydaje się Gombrowicz obserwowaniem innych zwiedzających:

Oprócz nas jeszcze z dziesięć osób... które podchodziły, przyglądały się, odchodziły... mechaniczność ich ruchów, ich ściszenie, nadawały im pozór marionetek, a oblicza ich były żadne w porównaniu $\mathrm{z}$ obliczami, które spoglądały z płócien ${ }^{44}$.

Widzowie stający oko $\mathrm{w}$ oko $\mathrm{z}$ obrazami Tycjana czy Murilla nie sa - zdaniem Gombrowicza - z tymi obrazami w żaden właściwie sposób związani, a ich twarze nie są podobne do twarzy namalowanych trzysta lat wcześniej. „Student szkoły sztuk pięknych”, „kobieta nie wiedząca co robić z czasem”, „kilku miłośników”, „osoby, które przybyły z daleka i zwiedzają miasto" ${ }^{45}$ (tacy sami, a możliwe przecież do wyobrażenia, że wręcz ci sami ludzie, których opisuje Białoszewski) nie przypominają Matejkowskich fizjonomii z Pocztu, nie noszą parasolek z wdziękiem z Renoira i nie uśmiechają się po leonardowsku.

\footnotetext{
${ }^{42}$ Witold Gombrowicz, Dziennik 1953-1956, wyd. II, Kraków 1988, s. 39.

${ }^{43}$ Tamże.

${ }^{44}$ Tamże.

${ }^{45}$ Tamże, s. 40.
} 
Według Gombrowicza kontakt z malarstwem ma na ludzi raczej destrukcyjny wpływ: „Nie po raz pierwszy daje mi się we znaki twarz sztuki, gasząca twarze ludzi żywych" ${ }^{46}$. Natomiast spoglądanie na dowolną „twarz sztuki” razem z Białoszewskim może twarze ludzi żywych rozświetlać w najbardziej nawet nieoczekiwanych momentach.

${ }^{46}$ Tamże. 